\title{
FEMINISMO E RECORTES DO TEMPO PRESENTE mulheres em revistas "femininas"
}

\author{
Tania Navarro Swain \\ Professora do Departamento de História da Universidade de Brasilia
}

\begin{abstract}
Resumo: Ouve-se dizer que o feminismo acabou. Que tudo já foi conseguido pelas mulheres, conquistas em todos os campos sociais. Apesar de evidentes modificações nas relações de gênero em alguns países do Ocidente, o que aqui se pretende analisar é a dimensão das representações sociais do feminino, constitutivas das configurações identitárias e corpóreas, já que presentes na apreensão do real. A mídia e as revistas femininas compõem um locus especial de análise da ação do discurso e das imagens modelando corpos e assujeitando-os a uma certa representação do feminino.

Palavras-chave: feminismo; revistas femininas; representações sociais; corpo e identidade sexual.
\end{abstract}

$\mathrm{Q}$ ue rumor é este, "trocas verbais no interior de uma sociedade", 1 que se ouve nas esquinas, nos bares, nas salas de jantar e nas de aula, nos ônibus superlotados e nos carros de luxo? O feminismo acabou? O infinito e insidioso ruído do discurso social sussurrado, explicitado, demonstrado, sugere a desnecessária continuidade de um movimento tornado obsoleto diante das "evidentes" conquistas das mulheres: no plano político, já podem votar e ser votadas, qual a queixa? São minoria nos altos postos legislativos e judiciários? Questão de tempo. No campo profissional as portas se abrem, para algumas eleitas. Questão de competência. Salários desiguais para tarefas idênticas? Os ajustes se fazem aos poucos...

Decreta-se assim no senso comum e na análise teórica o fim do feminismo: afinal, os gêneros não são igualmente construídos socialmente? Entretanto, colocando-se no mesmo assujeitamento ao social a constituição do feminino e do masculino, esquece-se facilmente o caráter hierárquico da generização do humano.

De fato, o ufanismo discursivo da igualdade de oportunidades não consegue encobrir a profunda polarização da sociedade ocidental em imagens esculpidas em formatos binários - mulher e homem -, cujos contornos assimétricos delimitam, autorizam, definem os papéis, a ação, o ser no mundo. Na prática social, a violência direta e indireta que povoa o cotidiano das mulheres com agres- sões físicas, humilhações, palavras, gestos, é apenas um marco de imagens e representações que instauram um corpo genitalmente definido e reduzido a um sexo biológico.

A noção de "gênero" criada pelos estudos feministas desmascara a ação do social contida nos discursos sobre a "natureza" humana e seu valor heurístico é incontornável; entretanto, a força compreendida nas análises da generização humana tende a se diluir nos aspectos demonstrativo e relacional como se o diagnóstico pudesse por si só curar o mal.

As composições de gênero determinam os valores e modelos desse corpo sexuado, suas aptidões e possibilidades, e criam paradigmas físicos, morais, mentais, cujas associações tendem a homogeneizar o "ser mulher", desenhando em múltiplos registros o perfil da "verdadeira mulher". Se o masculino também é submetido a modelos de performance e comportamento, a hierarquia que funda sua instituição no social desnuda o solo sobre o qual se apóia a construção dos estereótipos: o exercício de um poder que se exprime em todos os níveis sociais.

A análise dos mecanismos de condensação discursiva e representacional da carne em corpos sexuados permite detectar agentes estratégicos na reprodução, reatualização, ressemantização de formas, valores e normas definidoras de um certo feminino naturalizado, travestido em slogans modernos, em imagens de "liberação", cujos sentidos, 
constituídos em redes significativas, são expressão de um assujeitamento à norma instituída.

Algumas transformações formais, de fato, realizaramse em alguns países ocidentais em níveis legais e/ou jurídicos, graças justamente aos movimentos feministas, caracterizados pela sua multiplicidade, táticas e estratégias diversificadas diante de realidades. Mas o dinamismo e o alcance das mudanças - maiores ou menores de acordo com o país - têm-se reduzido ou mesmo regredido (Faludi, 1991), na medida em que as transformações não atingem as representações de gênero que constituem os corpos humanos em modelos de ser.

O que aqui se pretende argumentar é que, além do papel social definido em feminino e masculino, as representações e imagens de gênero constroem e esculpem os corpos biológicos, não só como sexo genital mas igualmente moldando-os e assujeitando-os às práticas normativas que hoje se encontram disseminadas no Ocidente.

Nessa perspectiva, as representações sociais são consideradas uma forma de construção social da realidade cuja mediação atravessa e constitui as práticas pelas quais se expressam. Para Denise Jodelet (1994:46), um pressuposto fundamental do estudo das representações sociais é o da “(...) inter-relação de uma correspondência entre as formas de organização e de comunicação sociais e as modalidades de pensamento social, vistas sob o ângulo de suas categorias, de suas operações e de sua lógica".

Assim, seja no rumor das conversas que fundamentam o senso comum, na literatura, no discurso científico, ou em tudo que é impresso ou falado, podemos encontrar representações sociais que instituem o mundo em suas clivagens valorativas, nos recortes significativos que definem as categorias de percepção, análise e definição do social.

A comunicação expõe assim sua própria constituição de categoria ao se expressar e as matrizes de inteligibilidade do discurso social podem ser apreendidas em sua análise; o discurso social é aqui entendido como “(...) tudo o que é dito e escrito em uma determinada sociedade; tudo que se imprime, tudo que se diz publicamente ou se representa hoje na mídia eletrônica. Tudo que se narra ou argumenta, se consideramos que narrar e argumentar são as duas maneiras principais de elaboração discursiva." (Angenot, 1989:13). Assim, a televisão, as novelas, os romances, as revistas em quadrinhos, as revistas em geral, os jornais, a internet, etc., em seu espaço de recepção e interação, veiculam representações sobre as mulheres, os homens, a sociedade. Imagens e textos compõem um mosaico que integra a maneira de se perceber o mundo e o desenho de sua positividade.

Dessa forma, se o discurso da mídia em seu dialogismo com o rumor social decreta o fim do feminismo, o campo conotativo do que é dito e do dizível indica a recuperação e/ou atualização de representações binárias, excludentes e hierarquizadas sob novas roupagens. Mulheres e homens continuam a ocupar lugares tradicionalmente traçados segundo sua "natureza" feminina ou masculina, esta mesma "natureza" desconstruída pelo feminismo contemporâneo. Longo é o caminho trilhado pelos feminismos plurais em suas estratégias e argumentações desde Simone de Beauvoir, quando a pretensa essência da mulher é desconstruída em uma simples frase que vincula o "ser mulher" ao "ser" social. ${ }^{2}$

Se a história das mulheres restitui de alguma forma a presença, a ação e a resistência das mulheres ao imaginário ocidental em narrações pontuais, o feminismo argumenta e analisa a construção, os mecanismos que produzem poder e reproduzem as desigualdades de gênero.

Entretanto, se as teorias feministas não cessam de expandir seu acervo de categorias e seu horizonte de análise, os movimentos feministas em sua prática social se vêem desautorizados e desmotivados diante da afirmação generalizada de que "o feminismo acabou" e que, sobretudo, o feminismo é uma prática anacrônica uma vez que, finalmente, "a igualdade já não foi alcançada?"

Jane Flax (1991) observa que a análise das relações de gênero, como são constituídas, pensadas e experimentadas, é uma meta básica do feminismo; sublinha, entretanto, a necessidade de apontarmos o domínio do pensável, ou seja: como reproduzimos estas relações em torno de valores e significados cuja aparência anódina não permite uma imediata apreensão das hierarquias implícitas? Como são representadas, em que constelações de sentido se inserem as imagens de gênero que são veiculadas no espaço midiático, locus privilegiado de um imaginário instituinte de relações sociais?

Nunca é demais destacar a démarche proposta por Foucault (1991) de inversão das evidências na análise do discurso social: buscar a vontade de verdade e os recortes discursivos que, no caso, constroem a naturalização de papéis. O discurso de verdade apóia-se na tradição, na ciência, na religião para definir a essência dos seres: uma identidade baseada em critérios arbitrários que se apresenta com um caráter atemporal, negação de toda historicidade, em asserções do tipo "eterno feminino", "prostituição, a mais antiga profissão do mundo". Para Foucault (1991:22), 
esta “(...) vontade de verdade que se impôs a nós há tanto tempo é tal que a verdade assim proposta não pode senão escondê-la", pois a evidência esconde em suas dobras a vontade de poder que a anima.

De fato, as representações sociais, estudadas em um tempo e local determinados sobre um corpus específico, são também reatualizações de imagens que permanecem alojadas nos nichos do interdiscurso, “(...) processo de reconfiguração incessante no qual uma formação discursiva é levada (...) a incorporar elementos pré-construídos, produzidos fora dela, com eles provocando sua redefinição e redirecionamento (...)" (Maingueneau, 1989:113).

Assim, no Ocidente, as representações das mulheres vêm sendo diabolizadas ou santificadas, e essas expressões compõem a noção de uma natureza sexuada selvagem, rebelde, má, cuja domesticação resultaria na imagem da "boa", da "verdadeira" mulher. Os discursos fundadores dessas "certezas" em torno do feminino vão de Aristóteles a Paulo de Tarso, passando por inumeráveis caminhos discursivos e temporalidades diversas, entre o medievo e a modernidade. (Swain, s.d.)

No saber instituído pela filosofia e pela história, a palavra dos "grandes homens" esclarece sobre a "verdadeira" natureza da mulher, repondo sem cessar, nos espaços interdiscursivos, representações pejorativas sobre o feminino que delimitam seu lugar no mundo, suas possibilidades e as práticas às quais ela deve se restringir. ${ }^{3}$

Alguns exemplos: Jean de Marconville, em 1564, invoca os gregos, os romanos, os textos bíblicos, os padres da Igreja para demonstrar a maldade das mulheres. Segundo ele, Adão, “(...) o mais dotado de todas as perfeições que todos os outros homens, foi entretanto vencido no primeiro assalto que lhe fez sua mulher". Ainda assegura que as mulheres não têm aptidões “(...) para manejar e conduzir coisas grandes e difíceis como costumes, religião, república e família, pois parecem ter sido feitas mais para a volúpia e o ócio que para tratar negócios de importância.” (Marconville, 1991:97 e 101).

Montaigne (apud Groult, 1993:83): “A mais útil e honrada ciência e ocupação para uma mulher é a ciência da limpeza"; Diderot (apud Groult, 1993:89): "A mulher tem em seu interior um órgão sucetível de espasmos terríveis que dela dispõem e suscitam em sua imaginação fantasmas de toda espécie" Schopenhauer (apud Groult, 1993:93): "Não deveriam existir no mundo senão mulheres de interior, dedicadas à casa, e jovens aspirando a isto e que formaríamos não à arrogância, mas ao trabalho e à submissão." E ainda: "A mulher (...) permanece toda sua vida uma criança grande, uma espécie de intermediária entre a criança e o homem, este o verdadeiro ser humano".

Proudhon (apud Groult, 1993:96-97), o "pai do anarquismo moderno" explicita seis casos em que o marido pode matar sua mulher, entre eles "a insubmissão obstinada, o impudor e o adultério", e acrescenta: "Uma mulher que usa sua inteligência torna-se feia, louca, (...) a mulher que se afasta de seu sexo, não somente perde as graças que a natureza lhe deu (...) mas recai no estado de fêmea, faladeira, sem pudor, preguiçosa, suja, pérfida, agente de devassidão, envenenadora pública, uma peste para sua família e para a sociedade". Nietzsche (apud Groult, 1993:102): "O homem inteligente deve considerar a mulher como uma propriedade, um bem conservado sob chave, um ser feito para a domesticidade e que só chega à sua perfeição em situação subalterna".

E isso sem citar a autoridade dos Rousseau, Freud, Hegel, Comte, Lutero, Lombroso, dos tratados médicos e dos manuais de confissão, da literatura e do teatro, da poesia, veiculando essas imagens que desqualificam e atrelam a mulher a um destino biológico e criam “(...) um campo de elementos antecedentes em relação aos quais se situa, mas que tem o poder de reorganizar e de redistribuir segundo relações novas" (Foucault, 1987:143). Assim a sedução perversa, a inferioridade física e social, a incapacidade intelectual, a dependência de seu corpo e de seu sexo, a passividade, vêm sendo reafirmadas em imagens e palavras que povoam o imaginário ocidental.

Essas imagens do feminino ancoradas na memória discursiva ${ }^{4}$ se incorporam às representações de mulheres atuais, transformadas, mas guardando as nuanças que fazem das práticas sociais um espaço binário assimétrico, cujas polarizações reforçam e justificam a divisão generizada do mundo. Ao feminino, o mundo do sentimento, da intuição, da domesticidade, da inaptidão, do particular; ao masculino, a racionalidade, a praticidade, a gerência do universo e do universal.

Apenas os discursos religiosos integristas ou de extrema direita se permitem na atualidade declarações de um tal teor pejorativo sobre as mulheres; entretanto, os ditos populares, as piadas, as letras de música e as representações sociais que encontramos em imagens e textos midiáticos reformulam o atrelamento da mulher a seu corpo e à natureza "feminina".

Os produtos culturais destinados ao público feminino desenham, em sua construção, o perfil de suas receptoras em torno de assuntos relacionados à sua esfera específica: sedução e sexo, família, casamento, maternidade e fu- 
tilidades. A ausência, nas revistas femininas, de debate político, de assuntos econômico-finaceiros, das estratégias e objetivos sociais, das questões jurídicas e opinativas é extremamente expressiva quanto à participação presumida, à capacidade de discussão e criação, ao próprio nível intelectual das mulheres que as compram. O feminino aparece reduzido a sua expressão mais simples e simplória: consumidoras, fazendo funcionar poderosos setores industriais ligados às suas características "naturais": domesticidade (eletrodomésticos, produtos de limpeza, móveis), sedução (moda, cosméticos, o mercado do sexo, do romance, do amor) e reprodução (produtos para maternidade/crianças em todos os registros, da vestimenta/ alimentação aos brinquedos).

Mulheres e homens, a "evidência" da diferença biológica seria o argumento último da necessária separação de esferas sociais baseada na diferença de sexos. Acompanha-se, entretanto, Judith Butler (1990) e Nicole Claude Mathieu (1991) quando questionam essa nova naturalização: a primeira afirma que o gênero só existe quando se materializa na prática do social, heterogênea em sua historicidade:

"O gênero pode também ser designado como o verdadeiro aparato de produção através do qual os sexos são estabelecidos. Assim, o gênero não está para a cultura como o sexo para a natureza; o gênero é também o significado discursivo/cultural pelo qual a 'natureza sexuada' ou o 'sexo natural' é produzido e estabelecido como uma forma 'prédiscursiva' anterior à cultura, uma superfície politicamente neutra sobre a qual a cultura age" (Butler, 1990:7).

Mathieu (1991:256) acrescenta que é esse gênero instituído que cria o sexo biológico, pois a heterogeneidade cultural de relações sexo/gênero "(...) nos leva a pensar não mais que a diferença dos sexos é 'traduzida' ou 'expressa' ou 'simbolizada' pelo gênero, mas que o gênero constrói o sexo. Entre sexo e gênero é estabelecida uma correspondência 'socio-lógica' e política". ${ }^{5}$ Ou seja, a importância dada ao sexo, ao aparelho genital, na positividade e divisão da sociedade, é ela mesma uma criação histórica e social.

Isso nos leva à questão dos corpos que se transformam em feminino e masculino num processo significativo que restitui, no discurso e na matéria, as representações valorativas que dão sentido às relações sociais. Assim, a sexualidade torna-se o eixo principal da identidade e do ser no mundo, fundamentando-se em valores institucionais tais como procriação, casamento, família; a hegemonia da heterossexualidade, prática sexual entre outras, como atesta a multiplicidade de culturas, torna-se naturalizada.
Essa montagem complexa compreende todo um sistema de representações e auto-representações sociais codificada em normas, regras, paradigmas morais e modelos corpóreos, que delimita os campos do aceitável, do dizível, do compreensível. Teresa de Laurentis (1987:5) chama essa engrenagem de sex gender system que seria "um construto sociocultural e um aparatus semiótico, um sistema de representação que confere sentido (identidade, valor, prestígio, localização no parentesco, status na hierarquia social, etc.) aos indivíduos na sociedade".

Na perspectiva feminista de detectar os mecanismos de produção e atualização deste quadro representacional Laurentis (1987:19) aponta para "as tecnologias do gêne$r o$ " que de forma discursiva ou imagética "(...) têm o poder de controlar o campo do sentido social e então produzir, promover ou implantar as representações de gênero".

Essas tecnologias no mundo contemporâneo possuem sua expressão paroxística no discurso mídiático. Como comenta Foucault (1988:180), “(...) Afinal, somos julgados, condenados, classificados, obrigados a desempenhar tarefas e destinados a um certo modo de viver ou morrer em função dos discursos verdadeiros que trazem consigo efeitos específicos de poder."

Apesar da proliferação dos textos e imagens no murmúrio contínuo e inesgotável do cotidiano ocidental, a apropriação social do discurso se dá em diferentes instâncias discursivas, lugares de fala, posições de autoridade que legitimam ou excluem, delimitam ou expandem as hierarquias e os valores definidores de sentido e de lugares sociais, na Ordem do Discurso, na economia de um imaginário em que se pode detectar a hegemonia das representações tradicionais e naturalizadas de gênero.

Regularmente o discurso social retoma a medicalização do homossexualismo, a dependência psíquica incontornável da mulher em relação a seu corpo sexuado na incapacitação que resulta da TPM (tensão pré-menstrual) ou na universalização dos "males" da menopausa, como veremos adiante. Esses tipos de asserções reduzem a multiplicidade da experiência à imagem da mulher, essencializada, partilhando igualmente a fragilidade de uma natureza que finalmente justifica e reitera seu lugar subordinado. A questão que se impõe é: como se pode confiar no julgamento, na palavra e no raciocínio de um ser subjugado periodicamente por nervosismos ou calores? Isso não seria apenas uma reformulação da imagem da "mulher histérica" ?6 $\mathrm{O}$ assujeitamento das mulheres e das próprias feministas a esse tipo de discurso revela a força de autoridade do discurso médico, divulgado e reafirmado pela mídia. 
Foucault (1991:110) afirma que “(...) em toda sociedade a produção do discurso é ao mesmo tempo controlada, selecionada, organizada e redistribuída por um certo número de procedimentos (...)" e as tecnologias de produção de gênero fazem parte integrante desta démarche, conjurando e ao mesmo tempo assimilando as transformações sociais conseguidas pelos movimentos feministas. Sob novas roupagens, quais as representações do feminino veiculadas pela mídia atualmente, nas propaladas reformulações das relações de gênero?

A análise de revistas "femininas" recorta, no universo discursivo, este "(...) conjunto de discursos que interagem num dado momento (...)" (Maingueneau, 1996:14) um lugar de fala que nos traz textos e imagens como objetos sociais e históricos, elaborados no social segundo códigos e significados pré-construídos; por outro lado são, também, produtores/ressematizadores das representações instituidoras da socialidade. Disputando um mercado milionário, entre publicidades, reportagens, conselhos, dicas, moda, receitas culinárias e de vida, procuram interpelar e conduzir as receptoras para um espaço de significações cuja proximidade da dóxa assegura sua possibilidade de leitura; existiria talvez um projeto pedagógico que urde a trama dos sentidos assim veiculados, numa retórica que busca "(...) convencer os outros de que, de fato, apesar de tudo, ainda se vive no melhor dos modos possíveis (...)"(Eco, 1993:174).

Os sentidos do mundo, assentados em valores e normas, expectativas e barreiras, definições e identidades, são assim constituídos em opinião pública, ciência, religião, lei, nas instâncias discursivas que regem e regulam a socialidade.

O mundo da comunicação contemporâneo é hoje talvez o único espaço sem fronteiras e a circulação de imagens e representações sociais é virtualmente sem limites; as matrizes de inteligibilidade partilhadas e veiculadas pela mídia atualizam, das profundezas da memória discursiva, imagens estereotipadas do feminino e do masculino, mas não apenas em um espaço cultural definido.

Assim, podemos sugerir a hipótese de que se o feminismo se desdobra hoje em teorias e estratégias plurais que apontam para a multiplicidade das situações e das condições materiais das mulheres, a mídia, em tempos de globalização, pretende a homogeneização da condição feminina e a recuperação da imagem da "verdadeira mulher" feita para o amor, a maternidade, a sedução, a complementação do homem, costela de Adão reinventada.
Com efeito, a mídia se localiza na noção de dispositivo, aventado por Foucault (1979:244) como “(...) um conjunto decididamente heterogêneo que engloba discursos, instituições, organizações arquitetônicas, decisões regulamentares, leis, medidas administrativas, enunciados científicos, proposições filosóficas, morais, filantrópicas". Assim, as tecnologias do gênero descritas por Laurentis aprofundam essa noção verticalizando-a na constituição das representações generizadas do humano.

Para transitar nesse universo globalizado da atualidade, em que a troca cultural é parte do mercado mundial, foram escolhidas para análise quatro revistas em dois países: Nova (jun, 1999) e Marie Claire (maio, 1999), revistas brasileiras, e Elle-Québec (janvier, 1999) e La Chatelaîne (décembre, 1998) da província francesa do Québec-Canadá.

Línguas latinas, matrizes culturais imbricadas, numa economia de trocas representacionais da América do Norte e América do Sul. A intenção é tentar observar como as representações de gênero constroem os corpos sexuados e as práticas femininas são assim homogeneizadas. ${ }^{7}$

O tom geral das revistas é de alegria, de confiança no futuro, certeza de poder conciliar tarefas, assumir os novos espaços abertos às mulheres sem perder um só grama de sua "feminilidade", perspectiva que "(...) em nada se distingue daquela ética da felicidade barata pela qual se rege uma civilização do lucro e dos consumos" (Eco, 1993:174). De fato, o que se nota é uma certa condescendência em relação à mulher profissional, cuja atividade seria apenas um acréscimo às suas tarefas habituais, nunca uma modificação da divisão "natural" do trabalho. O público-alvo é a mulher de classe média, jovem, com um certo nível de instrução e renda, cujas preocupações e interesses são presumidos nos apelos publicitários e nos temas desenvolvidos.

As capas das revistas brasileiras Nova e Marie Claire apresentam chamadas que indicam as matrizes de sentido sobre as quais se apóiam o corpo e seus contornos, a sexualidade heterossexual, a sedução, o casamento e a maternidade. O corpo tecnológico, refeito, remodelado para seguir o modelo de mulher cujas imagens povoam a revista aparece em ambas: plástica na barriga e transplantes em Marie Claire (MC); em Nova, aumento dos seios com silicone. Na rede discursiva texto/imagens dessas revistas, as publicidades vêm reforçar os sentidos e as representações propostas nas capas, como veremos mais adiante.

Em MC, as três primeiras chamadas discutem a sexualidade e o casamento: "As fases da separação: da dor ao 
alívio"; "Lua-de-mel: como era e como ficou"; "Orgasmo, a ginástica sexual que aumenta o poder feminino". Um depoimento - lugar de fala da leitora - anuncia a maternidade: "um milagre de amor salvou meu filho". Um belo rosto de mulher compõe a capa, moreno, olhos castanhos, cujo sorriso anuncia o bem-estar da mulher brasileira.

A capa da revista Nova é mais provocante: uma exuberante loura de olhos azuis, seminua, apenas envolta em gaze azul: mulher versão Barbie, o retorno infindável? As chamadas estão todas voltadas para a sexualidade e a sedução: "14 histórias inconfessáveis de ousadias sexuais"; "O que você faz para engatar ou destruir o namoro"; "Terapia sexual é uma saída para casamentos na corda bamba?"; "50 homens charmosos e solteiríssimos que querem receber sua mensagem". De fato, as duas revistas são construídas em função de um personagem cuja presença é incontornável e em torno do qual giram as mulheres incansavelmente: o homem.

Em ambas as revistas o corpo é central, pois é a partir de sua capacidade de sedução que os demais elementos da rede discursiva se integram. O cyborg analisado por Donna Haraway, o corpo tecnológico, é evocado pelo discurso sobre o transplante, do qual se trocam as peças na luta contra a morte; a plástica na barriga e as publicidades de cosméticos e cremes rejuvenescedores apelam à eterna juventude, ao corpo produzido: o modelo corporal está finalmente ao alcance de todas, na luta contra o tempo e as imperfeições. Com a cosmetologia, nenhuma mulher precisa ser feia, uma vez que a beleza é condição sine qua non para o romance e a felicidade.

As publicidades referentes ao corpo em MC apontam para a beleza possível, mostrando às mulheres como elas PODEM ser. "Livrei-me da barriga e das recordações tristes" diz uma leitora em MC: o excesso no corpo remete à tristeza e à infelicidade.

O sumário de MC transita entre reportagens que articulam valores tradicionais (entrevista com Adélia Prado e comunidade tradicional no Rio Grande do Sul) e matérias sobre duas personalidades masculinas, decoração e interior (interesse principal e locus específico da mulher), problemas de relacionamento de casais e é claro, Moda, Beleza, Saúde e dicas para uma Boa vida).

A única matéria de cunho político strictu sensu referese às "viúvas e órfãs de Pinochet", na qual aparecem como guardiãs de uma memória - de um pai ou marido, cujas imagens são predominantes. "Até hoje muitas mulheres continuam procurando saber o que aconteceu com seus parentes desaparecidos". Apesar do corpo da matéria apontar para mulheres que foram torturadas, violadas e assassinadas, a construção do texto e as imagens as tornam espectadoras e auxiliares das verdadeiras vítimas - os homens, que perderam a vida pela liberdade. A resistência das mulheres à ditadura não aparece senão como a dor da perda, mote das chamadas e das fotos: a corda sensível é a quebra familiar, o registro da emoção e do individual, único aparentemente capaz de motivar as mulheres e fazêlas respeitadas nesta "invasão" do espaço público.

A sexualidade aparece explícita nas três primeiras reportagens: na matéria sobre a lua-de-mel, a superfície discursiva da chamada mostra um caminho evolutivo de mudanças no comportamento sexual. Podem-se destacar algumas palavras que sustentam o texto nas palavras da avó: ingênua, choque, dor, medo, vergonha, ansiedade. Mas "meu marido era um lorde (...) eu tinha de deixar (..) afinal o casamento tinha de ser consumado, era nossa obrigação". Para a filha, a lembrança da noite de núpcias invocava "ansiedade, nervosismo, dor, vergonha; "a virgindade era um bem a ser preservado. Na verdade a gente falava muito, mas sabia pouco". Prazer? “(...) senti prazer, um prazer de estarmos juntos (..) tinha de ser e ele foi supercarinhoso e paciente". Em comum as matrizes de sentido: medo, vergonha, obrigação, falta de prazer e a idealização de um marido gentil e compreensivo.

Quanto à terceira geração, na primeira relação sexual "Eu não tinha vergonha, (...) não doeu, não sangrou, mas não senti prazer”. O casamento, feito “(...) porque as famílias queriam" mostra uma opção moderna, que dispensaria o institucional; seu relato, entretanto, é o único que enfatiza os rituais realizados nos mínimos detalhes, o que é significativo sobre a importância da cerimônia para os próprios noivos. O relato é finalizado com a ênfase dada à transmissão da experiência para a filha "(...) passando para ela o máximo que puder do que é a relação com um homem, os sentimentos, a beleza, sem tabus (...) inspirar na nossa filha esse sentimento de algo muito natural e bom."

Esses depoimentos, numa linha de progresso, apóiam o caminho inexorável de um relacionamento cada vez melhor entre os gêneros, exemplificado no artigo pelo discurso da atualidade. Locus de gentileza, afeto, estabilidade, a família é exaltada na transmissão dos valores mais tradicionais e a sexualidade no casamento, vestida de modernidade, afirma a boa ordem do mundo. Essa é, portanto, a sexualidade correta, ligada ao que é "natural e bom".

Essa matéria se atrela à naturalização do institucional e ao obscurecimento de sua historicidade; como sublinha 
Adrienne Rich (1981:17), "Em nenhum dos livros que tratam da maternidade, dos papéis e relações sexuais, das normas sociais para as mulheres, leva-se em consideração a heterossexualidade obrigatória como instituição capaz de afetar profundamente todos os fatos sociais; e a idéia de 'preferência' ou de 'orientação inata' não é, da mesma forma, posta em questão".

Na mesma linha da tradição e família, encontra-se uma longa entrevista com Adélia Prado, para quem o lugar de fala e de autoridade é logo estabelecido: "a maior poeta brasileira viva", que "(...) defende valores cada vez mais contestados e escreve textos cada vez mais admiráveis." Com 41 anos de casada, fé no "sacramento do matrimônio", mãe, avó, católica, dona de casa, o perfil traçado fundamenta o discurso em torno de alguns eixos: fé, estabilidade, valor espiritual do casamento. Adélia Prado afirma que "(...) as feministas me acham antiga demais da conta" e a revista apressa-se em afirmar: "Mas os críticos são quase unânimes em reconhecer o talento e a força desta teologia poético-pessoal e feminina".

A oposição feminino/feminista reforça a percepção do senso comum: o feminismo é desqualificado pela afirmação do feminino, ligado aos valores das "verdadeiras mulheres" assegurados pelos críticos, pelo mundo masculino.

Adélia Prado tem sua definição de feminino: "capacidade de dizer sim, de se dobrar, de aceitar a condição de perdão radical." Da mesma forma indica que: "Uma coisa que me aflige é o direito da mulher. Eu fico com uma vergonha na hora que dizem isso. Porque me inferioriza, sou ofendida enquanto ser humano (...) acho que já está tudo lá nos direitos humanos." A palavra "vergonha" sugere a inadequação total de reivindicações que desestabilizariam o natural das posições definidas para mulheres e homens - humanos, cada qual em seu lugar, decisão divina.

O discurso de Adélia Prado nessa revista nega a condição subordinada da mulher, nega a violência social e institucional que hierarquiza e marca os indivíduos sexualmente. Esses comentários seriam apenas desprezíveis se não estivessem inseridos em uma rede discursiva que os revestem de legitimidade para o senso comum, adensando a dóxa da inscrição corporal.

Por outro lado, para ela, escrever é um ato masculino: “(...) vergonha de fazer poesia nunca tive, mas era do ofício que tinha vergonha”. Usurpação do lugar do homem, opróbio do deslocamento da ordem das coisas, da ordem do Pai: aos homens o intelecto, às mulheres o sentimento, a intuição. "Cada macaco no seu galho" diz o ditado.
Adélia Prado continua: “(...) qualquer ato criativo eu sinto como um ato masculino. De fato eu sou um homem neste sentido, quando estou escrevendo." Assim, ser agente no mundo é privilégio do ser masculino; anulação total, negação do ser feminino que se procura afirmar: a criação para a mulher é apenas ligada à reprodução. "Virgindade, casamento, é necessário passá-los para os filhos", conclui.

A repórter marca o lugar da recepção esperada: "Saí de sua casa com uma inveja boa, querendo ser um pouco como ela (não fosse eu estragada de nascença) só para acreditar no que e como ela acredita." O desalento, a descrença marcam essa fala que aponta para a retomada de valores e crenças tradicionais. Quem sabe não éramos mais felizes?

A revista MC continua a discursar sobre a sexualidade e a chamada agora é: "Ginástica íntima: técnicas milenares e aparelhos que aumentam o prazer da mulher". No corpo do texto a matéria versa sobre a "contração voluntária dos músculos circunvaginais, a fim de induzir sensações eróticas no pênis durante o ato sexual". Prazer de quem?

Uma citação de Jorge Amado completa o texto em um quadro, em destaque: "uma mulher pode ser feia de aparência, pior de formas, mas se a boca do corpo for de chupeta, trata-se de diamante puro". A grosseria da frase teria foros libertários? O fato é que aqui a mulher é apenas uma vagina, não importa seu aspecto físico.

O deslocamento entre o título e o texto marca o próprio deslizamento da sexualidade da mulher para a do homem, a que se torna central na matéria. A jornalista afirma ainda que "idolatradas pelos homens, muitas 'pompoaristas' não divulgam a técnica para não aumentar a concorrência": assim, aquelas que compraram a revista esperando conselhos para um maior prazer pessoal, se vêem conduzidas a um universo de concorrência e sedução, em que seu corpo é um simples aparelho masturbatório.

Por outro lado, na seção de cartas, um comentário sobre um bordel para mulheres: "Em algum lugar deste mundo as mulheres podem exercer suas vontades, fantasias e desejos sem o menor problema ou constrangimento." A prostituição, expressão paroxística da violência social, torna-se aqui o locus naturalizado de expressão livre do desejo: a liberação sexual é equiparada à prostituição, estratégia discursiva comum tomada como justificativa da objetificação e mercantilização humanas.

As publicidades compõem a rede que estabelece o lugar, a conduta adequada, o perfil psicológico da mulher: numa delas, o amor da mãe pelo filho torna-se admiração sem limites da mulher pelo homem, pois ele ensina-lhe a usar Nescafé. 
Os anúncios de carro revelam a relação das mulheres com a máquina: aparência e segurança são os motes. Numa delas a família feliz, duas crianças, o pai dirige, a mãe olha-o com adoração e põe a mão em sua perna. $O$ carro para as mulheres é uma extensão de sua casa, extensão de seu papel e de suas obrigações.

Além da moda e da cosmetologia, cujas publicidades compõem cerca de um terço da revista, anúncios de sabão em pó: "todo o mundo tem de escolher entre o que precisa fazer e o que gostaria de fazer (...) enquanto Ariel trabalha, você tem todo o tempo livre para dedicar a sua família, a sua casa, a você mesma". "Dia das mães. Se depender da gente pode-se chamar Dia da Independência assinado: produtos Maggi."

A divisão de trabalho é aqui naturalizada ao máximo: entre precisar/querer, a opção é obrigatória, e facilitar o trabalho de casa permite uma dedicação ainda maior à ... casa. Por último, eventualmente, a si mesma. De toda forma, a mulher foi destinada à resignação e ao sacrifício, como diria Adélia Prado. A independência, para as mulheres, se resume a fazer comida com maior facilidade. Em SEU lugar: a cozinha.

A revista Nova já em sua denominação apela para a idéia de transformação, de modernidade: a "nova mulher" deve aí encontrar a sua imagem. As chamadas da capa referem-se a práticas sexuais, possíveis transgressões, casamento, namoro, remodelagem do corpo: "14 histórias inconfessáveis de ousadias sexuais, a gente nem imagina do que as mulheres são capazes!" (O lugar de fala aqui é externo e na perspectiva binária da revista, só pode ser masculino - seria um convite a seus olhares?) "Negra e vitoriosa: volta por cima do preconceito" "50 homens charmosos e solteiríssimos querem sua mensagem"; "Terapia sexual para casamentos"; "Engatar ou destruir um namoro - os homens revelam"; "Idéias espertas para trabalho extra"; "Aumento do seio com silicone". Dessas chamadas, quatro são relativas ao relacionamento com um homem e uma refere-se à busca da perfeição corpórea, marco de sedução.

Nos artigos e reportagens, uma personalidade em destaque, pondo em relevo sua carreira, expectativas de trabalho: um homem. Duas mulheres aparecem também como tema de reportagem: uma é a mulher mais elegante do Brasil e outra é Betty Faria, atriz, mas a ênfase aqui é dada à sua vida particular e sobretudo amorosa. Os domínios de atuação são assim claramente demarcados.

Outras duas matérias se debruçam sobre as fantasias sexuais e problemas amorosos, uma sobre o casamento e dentre as " 21 coisas a fazer antes do ano 2000 ", a primeira é "fazer as pazes com o corpo" e a segunda, "honrar a palavra" da qual o exemplo dado é "fazer dieta".

A reportagem especial é sobre "paquera". Seguem-se moda e beleza (ao alcance de todas), cartas, horóscopo, dicas, novidades, nudez, mulher liberada. As categorias axiais permanecem as mesmas: corpo, sedução, amor.

As publicidades de moda, culinária, perfumaria e beleza, com ênfase para o rejuvenescimento, compõem quase metade da revista. "Quero ser seu par": 14 páginas sob este título mostram em grande formato casais em posições claramente sexuais ou de apropriação. Os seios voltam à baila, explicitando que a perfeição está ali, próxima: “Aumenta o volume! Se você não nasceu com seios perfeitos pode optar pelas moderníssimas próteses de silicone. Levantamos tudo sobre o assunto!", em seis páginas. O corpo da mulher desenha-se assim sob o olhar do outro, aquele a ser seduzido, aquele que faz de mim um sujeito dotado de significação social.

Que corpo é este, construído em todas suas linhas e desenhos; que corpo é este contra o qual devem se erigir o mundo feminino e a indústria de cosméticos/perfumaria/ginástica/produtos dietéticos/medicina/pesquisa? Para melhor domesticá-lo, para controlá-lo e mostrar que, neste caso, a natureza pode e deve ser contornada, pois todas as mulheres têm ao seu alcance a BELEZA, caminho para o amor, o casamento, o jogo da sedução e da felicidade.

Tomadas ao acaso, as superfícies discursivas de produtos de beleza: “... o mais revolucionário tratamento de beleza contra o processo de envelhecimento e combate aos radicais livres"; “....aparelho especialmente desenvolvido para modelar o seu corpo, quando você não tem tempo para fazer exercícios" (ao lado de uma dançarina do ventre com o rosto velado e seminua). "Segredos da natureza para renovar sua pele, cabelos e sentidos"; "Novo Chic... não pense no custo. Pense no benefício. (mulher de calcinha e sutiã sobre um fundo azul de um rosto em close de um homem); "Agarre seu homem pelos cabelos". De fato, as mulheres se vêem pelo olhar "panóptico" masculino, que as constrói em seu reflexo no espelho e em sua representação mental.

Num metadiscurso, a revista faz um anúncio dela mesma - Nova Beleza - com a chamada principal: "Todas as respostas para você ter um bumbum perfeito: exercícios, óleos, dietas..." e outras compondo a próxima capa: "a primeira noite com ele: como deixar seu corpo macio, cheiroso, gostoso de pegar"; "cabelos ondulados, cacheados, crespíssimos"; "os 22 melhores cremes... para você 
começar já!”; “Decidi mudar radicalmente meu visual. E consegui!"; "Seios que parecem maiores, barriga quase invisível. As lingeries que modelam seu corpo". Mulhercorpo?

Para Susan Bordo (1997:19-20), o corpo funciona como uma metáfora da cultura e esta densa rede discursiva tece as malhas simbólicas e normativas da definição do feminino. Afirma a autora que "Por meio de disciplinas rigorosas e reguladoras de dieta, maquiagem, e vestuário princípios organizadores centrais do tempo e do espaço nos dias de muitas mulheres - somos convertidas em pessoas menos orientadas para o social e mais centradas na automodificação". E esse combate cotidiano é incitado, conduzido e levado aos extremos pelo dispositivo da sexualidade definido por Foucault (1976), no qual as tecnologias de gênero afunilam a performance na construção de corpos sexuados, no esquema binário e valorativo que funciona e oscila nos registros da sedução, posse, romantismo, apropriação.

Ainda no "ramo publicitário" os anúncios de carro expressam em suas superfícies discursivas uma certa representação da mulher: "conforto e segurança" (antes de tudo, pensar no transporte das crianças); "novo design, novo conjunto ótico: faróis e pisca numa única peça de policarbonato transparente" (alta tecnologia para o mundo feminino); "pára-choques envolventes na cor do veículo que suporta pequenos choques" (mulher dirige mal e só conhece do carro a cor), novo revestimento com toque suave", (próprio das damas); "novo quadro de instrumentos com conta-giros de série e iluminação por leds azuis de alta intensidade e filetes em vermelho" (cores e luzes, atrativos maiores) "computador de bordo ... nova regulagem no comando de válvulas e injeção, deixando o carro ainda mais gostoso de dirigir" (detalhe apenas: computador, injeção eletrônica - não se assustem, é agradável para dirigir). Poderia ser a descrição de um carrinho de brinquedo mas "combina com seu estilo de ser" e como é um anúncio para a "Nova Mulher" conclui: "irreverência nas ruas."

O capítulo "sexualidade" nessa revista tem três partes: terapia, fantasias e entrevistas com homens sobre como vêem as mulheres, nas quais a questão é vê-las moldes "para casar" ou "para outras coisas". As respostas se dividem em partes iguais: a primeira metade acha um absurdo essa divisão, mas suas afirmações ainda constroem um mundo separado para homens e mulheres. Assim, a afirmação "o que faço com outras mulheres posso muito bem fazer com minha namorada" supõe a multiplicidade de parceiras. Estaria sua namorada no mesmo registro, seria isto aceitável? Ou apenas uma reafirmação da dupla moral, a sexualidade múltipla para os homens e a monogamia para as mulheres? "Adora badalação ... e nem por isso é uma vagabunda". O que é ser uma vagabunda? Quais os limites, quais as margens? "Cheguei à conclusão que somos iguais", pensamento profundo, solitário, inovador e moderno, nada a ver com as transformações conseguidas a duras penas pelos movimentos feministas.

A outra metade dos entrevistados afirma claramente suas expectativas: “... por mais que um homem seja moderno ele não consegue pensar em casamento quando se relaciona com uma mulher que faz questão de sua própria liberdade... mesmo que isto não a comprometa em nada"; "prefiro uma mais quietinha, que confie em mim e não me dê dor-de-cabeça com mania de independência"; "para casamento com certeza prefiro uma garota serena, caseira e natural".

As palavras destacadas acima compõem por si só um texto de advertência às mulheres: o espaço de domesticidade, a reserva própria ao feminino, a volta à "natureza" são condições sine qua non para o casamento. Nos anos 70, Germaine Greer (1971:295) apontava essa dupla face do casamento: "Cada esposa deve se contentar de seu lar e de sua vida familiar enquanto que para o homem trata-se apenas de um lugar de refúgio para onde se retira como um guerreiro cansado (...)."

Esses homens, que assim se expressam, são jovens entre 25 e 35 anos, nos anos 90, nascidos já em meio ao debate engendrado pelo feminismo; suas representações sociais, entretanto, continuam presas aos esquemas binários do mundo, de dupla moral e do binarismo implícito nas práticas sociais, sejam elas econômicas, morais, relacionais, sexuais, instituidoras de um mundo cindido "naturalmente", em masculino e feminino.

A revista constrói sutilmente sua rede de representações em outras reportagens: uma leitora queixa-se que seu noivo a subestima, suas opiniões, ações, "não me considera capaz. Perguntei se acha que sou burra, ele apenas sorriu, como se estivesse dizendo mais uma bobagem." Essa superior condescendência é atenuada pela revista que afirma: "Ele é uma vítima do mecanismo que o obriga a ser assim (...) mas para dominar, precisa de uma cúmplice, dê-se ao respeito."

Esse ato retórico de inversão constrói um campo de significação e persuasão em que a vítima é transformada em ré ou cúmplice: de um lado explica socialmente a atitude do homem e de outro acusa a mulher. Nos casos de estupro, agressão, assédio, violência conjugal, de quem é 
afinal a culpa? Já diz o ditado: "se você não sabe porque está batendo, ela sabe porque está apanhando".

Logo em seguida, uma entrevista com um músico muito liberal, que adora as mulheres com uma "saudável rebeldia". Entretanto afirma que "garotas doces, meigas e certinhas, tímidas e passivas exercem um grande fascínio sobre os homens". Não chega nem a ser uma retórica paradoxal: de um lado, uma certa rebeldia, moderna, mas dentro de limites precisos, pois no jogo da sedução é o papel tradicional, "natural" da mulher que vai atrair e "fisgar" os homens.

Outra reportagem refere-se às "dez fantasias sexuais mais quentes": nas dos homens encontram-se o voyerismo e o homossexualismo. Mas a revista previne, para deixar claras as fronteiras sexuais: "não, ele não é gay, é só uma curiosidade positiva". Sadomasoquismo é outra fantasia masculina mas a relação natural entre os gêneros aí fica explícita: dominador/dominada".

Ser amarrada é uma das fantasias femininas favoritas; amarrar, um sonho tipicamente masculino. "Tem a ver com a obtenção do poder ou a renúncia a ele". Ou seja, mesmo no nível da fantasia não há disputa de lugares: as mulheres renunciam ao poder (passividade, submissão, aceitação) e os homens exercem-no.

A simulação do estupro é outra fantasia masculina e diz a revista: “(...) forçar uma mulher não está relacionado à violência mas com a vontade que o sujeito tem de submeter a parceira por meio de uma técnica fantástica. Ela começa dizendo não depois muda de idéia, porque é incapaz de resistir ao gostosão. Para ele é uma viagem do ego. Ninguém se machuca e a vítima também se diverte." Essa "fantasia" nega a violência do corpo usado, da humilhação, do desprezo e da negação da individualidade; diminuída, banalizada, apresentada como um jogo, lúdico e prazeroso - uma técnica fantástica. "Viagem do ego, incapaz de resistir ao gostosão." Como negar a força das palavras, a força dessas imagens que saltam do texto e interpelam as emoções? Como negar que essa retórica persuade e estimula a agressão, reafirmando antigas fórmulas como: "ela começa dizendo não"?

Assim, vemos a mídia atuando na tessitura da rede representacional reafirmando e fazendo funcionar o poder generizado em “(...) nível do processo de sujeição ou dos processos contínuos e ininterruptos que sujeitam os corpos, dirigem os gestos, regem os comportamentos, etc." como explicita Foucault (1979:182).

O homossexualismo está entre as fantasias e ousadias sexuais das mulheres mas a revista desculpabiliza “(...) só porque tem a idéia não quer dizer que vai ser obrigada a cortar o cabelo e pôr um terno". O estereótipo indica que uma passagem rápida pelo desejo sáfico não pode desviar do caminho correto, o que reforça no campo das representações sociais “(...) a convicção das mulheres de que o casamento e a orientação sexual para os homens são componentes inevitáveis de sua existência", como afirma Adrienne Rich (1981:23).

Por outro lado, sexo oral, sexo romântico, ser considerada irresistível aparecem como fantasias sexuais ousadas. Que tipo de relação sexual têm as mulheres "modernas" que lêem Nova? Que tipo de relação podem considerar satisfatória se nessas fantasias "ousadas" a sedução é mais importante que o sexo?

Nas fantasias aparece, é claro, como contraponto, o "sexo contra sua vontade" e a revista explicita: "elementos de conquista à força, não de dor e violência". Agir como prostituta é também uma fantasia das mulheres "sexualmente inibidas", pois informa a revista Nova, "o pagamento é confirmação do poder de atração, você tem uma coisa tão almejada que ele está disposto a desembolsar dinheiro por ela." A mulher reaparece aqui como a representação de seu corpo ou uma parte dele e a prostituição, exacerbação da violência social, é tratada como um estágio superior da sedução.

Essas são estratégias discursivas de construção de gênero e seu efeito de poder é a construção de um corpo biológico generizado que traz, como sublinha Foucault (1979:22) “(...) em sua vida e sua morte, em sua força e sua fraqueza, a sanção de todo erro e de toda verdade (...)". Verdades construídas, datadas, que circulam no social com a força da evidência, com o selo do natural e do inquestionável quando se trata de corpos sexuados feitos mulheres.

Outra cultura, outro espaço, outra materialidade: a província canadense de Québec, de língua francesa. O momento: Natal. A revista, La Chatelaîne, que logo marca seu lugar de fala: "a revista mais lida do Québec". As chamadas da capa enquadram um belo e jovem rosto de mulher, sorridente: "Viagra: a vingança dos homens"; "Educação, quando os pais não sabem dizer não"; "Michel Rivard: a felicidade reencontrada"; "Natal: seja bela para as festas"; "Não procure mais: 15 páginas de presentes fabulosos". A trama discursiva se organiza em torno do consumo, da beleza, da família, da sexualidade e dos homens. A capa sinaliza assim o conteúdo significativo da revista.

Abrindo a revista, em duas páginas uma publicidade de perfume na qual um homem beija uma mulher. Consu- 
mo, sedução, amor, o tríptico das revistas femininas. A publicidade tem um papel notável nessa revista, na recuperação e reafirmação de estereótipos: numa delas (que se repete na revista Elle) uma mulher executiva, sobrancelha levantada, lábios estreitos, braços cruzados, tailleur estrito, cabelo preso, sentada em uma cadeira de espaldar alto e reto, atrás de uma mesa sobre a qual repousam caneta, óculos, agenda. Na placa em que deveria estar seu nome, que em francês se escreve NOM, está escrito, porém, NON, ou seja, a negação: não.

Essa imagem negativa, de dureza e severidade para uma executiva, imagem rígida de uma mulher no exercício de uma profissão de comando, é colocada em um campo significativo e polissêmico com a simples palavra instalada em sua frente: Não. Não à profissional? Não à mulher severa? À mulher em posição de poder? À mulher que não se adapta ao modelo? À mulher sem os atributos "naturais" da feminilidade? "No Natal, ofereça algo doce a quem mais precisa" diz o texto. E sublinha: "para as que precisam se dar prazer". Imagem e texto, ato retórico desconstrutivo da representação da mulher que trabalha, que decide, que manda, pois perde sua doçura, sua suavidade, e sobretudo, seu prazer - de ser mulher.

As publicidades nessa revista concentram-se em produtos de beleza (35 páginas) que asseguram a juventude, a perfeição em detalhes do corpo: maquiagem, cabelos, unhas, pele, lábios, cílios, apontando para as possibilidades infinitas de correção de imperfeições e da passagem do tempo. A "arte" da maquiagem é a arte do disfarce, mas isto supõe que o rosto da mulher sem pintura seja defeituoso. “(...) As tecnologias da feminilidade são praticadas pelas mulheres contra este pano de fundo da percepção de um corpo deficiente; isto explica seu caráter muitas vezes compulsivo e ritualístico", sublinha Sandra Bartky (1988).

Por outro lado, 32 páginas e publicidades sobre cozinha e comida trazem conotações sexuais, familiares, sedutoras. A mulher é a provedora ou a que "pega o homem pelo estômago". Uma delas é uma receita para a sedução, a respeito de trufas com chocolate branco: "depois de uma, seu homem lhe dá a lua; depois de três, renega a cozinha da mãe; depois de cinco, começa a compreender o que significa "preliminares."

O grande número de apelos à degustação de receitas ou as fotos de doces suculentos é uma contradição constante com as imagens oferecidas como modelos de beleza, diáfanas, magras, magras, magras. Essa contradição impregna a vida das mulheres ocidentais pois, como explicita Susan Bordo (1997:25), “As regras dessa construção de feminilidade (...) exigem que as mulheres aprendam como alimentar outras pessoas, não a si próprias, e que considerem como voraz e excessivo qualquer desejo de auto-alimentação e cuidado consigo mesmas. Assim, exige-se das mulheres que desenvolvam uma economia emocional totalmente voltada para os outros."

Outras fontes de representações sobre as mulheres são as publicidades de carros: nestas, os textos são longos e retomam o senso comum. Na descrição do automóvel enfatiza-se o espaço e as "portas com duplas fechaduras", ideal para transportar as crianças; por outro lado, "os instrumentos fáceis de ler", ajudam a pobre mulher a compreender uma máquina misteriosa para sua mente limitada. Ou então, o que importa são as linhas e a aparência: "top model: elegância, raça, grife, conforto,"; "todas as suas esperanças alcançadas: espaço, conforto, rádio, regulador de velocidade e ah! 150 cavalos!" De fato, a performance do motor é secundária, todos sabem que as mulheres só conhecem dos carros as cores. Facilidade, conforto, segurança, espaço; adjetivos: elegância, beleza, grife. A venda de carros retoma como eixos a aparência, a utilidade familiar, a futilidade, o acessório em lugar do essencial, e sobretudo a relação "natural" da mulher com a máquina: a incapacidade de compreendê-la, de avaliá-la.

A diferença entre homens e mulheres é tomada como tema de uma das reportagens da revista e o subtítulo sugere uma modificação representacional: "os geneticistas exageram!" Da Université Laval, única universidade no Québec que tem um programa de "Estudos Feministas" com diplomação específica, vem o interlocutor que responde às questões da revista: é um homem, antropólogobiologista. Nessa escolha, a revista reforça a idéia da autoridade masculina, voz que pode esclarecer as dúvidas de todas as leitoras "modernas", ávidas de aprendizado.

Segundo ele, os antropólogos contestam que as diferenças sejam naturais mas em nenhum momento fala do papel do feminismo nessa contestação do papel "natural" atribuído ao feminino e ao masculino. Afirma que "na maior parte das sociedades de caçadores-colhedores que existiam antes da agricultura, as mulheres se dedicavam à colheita e os homens à caça". Essa universalização é totalmente desprovida de fundamento, na medida em que os dados a respeito dessas sociedades - indícios - estão sujeitos à interpretação dos analistas impregnados de suas representações sociais. Nada pode provar essa divisão de trabalho, a não ser as pressuposições contidas em suas próprias concepções de papéis de gênero. As generaliza- 
ções históricas a respeito das relações mulheres/homens são fruto de um positivismo anacrônico que se fundamenta apenas na afirmação de suas premissas: é natural porque é, e sendo assim sempre foi.

E ele continua: "Seria porque as mulheres são menos hábeis na caça? Isso está longe de ser provado!" Mas sua afirmação anterior solidificou a universalização das relações sociais generizadas desde o início dos tempos, artifício discursivo em que a força da representação tradicional apaga a afirmação contrária.

E apesar de afirmar que o cultural tem mais força que o biológico, continua dizendo que "naturalmente creio que existe uma parte de explicação biológica (...) em milhares de sociedades estudadas pelos antropólogos não encontramos nenhum exemplo em que as mulheres exercessem o poder como os homens o fazem em nossas sociedades antes do feminismo". Seu discurso recortado pode significar totalmente o contrário do que anuncia o título da matéria e se apóia na rede de sentidos estabelecida pela revista.

A última pergunta: "Para resumir, podemos dizer que a diferenciação dos papéis de homem e mulher é o resultado de um caminho cultural e de uma predisposição biológica?" Resposta: "Indubitavelmente. E esse caminhar cultural não acabou. Nada nos permite afirmar que em alguns séculos as mulheres não ocuparão mais espaço do que os homens na cena pública.”. Ficamos todas felizes com essa perspectiva secular, tempo necessário para transformar a biologia rebelde das mulheres em seres aptos ao poder público.

Em outra matéria, chamada da capa "Viagra: vingança dos machos contra as feministas", o feminismo é colocado CONTRA os homens, reafirmação do senso comum: feministas = mal-amadas, viragos, lésbicas. O depoimento do editor de Penthouse atualiza o discurso do século $\mathrm{XV}$ sobre as feiticeiras que castravam os homens: "O feminismo emasculou o macho americano e esta emasculação engendrou problemas orgânicos". O Malleus Maleficarum, manual dos confessores de 1486 se inquieta sobre essa questão: “(...) pergunta-se se as feiticeiras, pelo poder do demônio, podem verdadeiramente e realmente cortar o membro ou somente dar a impressão ilusória disto? (...) Ninguém duvida que certas feiticeiras façam coisas espantosas em torno dos órgãos viris; muitos o viram, muitos ouviram falar." (Institoris e Sprenzer, 1990).

O sentimento de castração adviria da perda ou do questionamento do poder sobre as mulheres, com seu discurso de igualdade? A retomada do vigor sexual - sinôni- mo e símbolo do poder - seria a recuperação do poder sexual/social?

Mas a riqueza significativa dessa reportagem não se exaure facilmente: "para as mulheres de uma certa idade, sobretudo se estão na menopausa e não seguem a hormonoterapia (que luta contra a secura vaginal), não têm necessariamente vontade de ser solicitadas novamente". O papel passivo da mulher na prática sexual é aqui reafirmado; a sexualidade destina-se apenas àquelas leitoras da revista, jovens e em idade de reprodução, que cuidam de sua beleza e seu corpo, são sedutoras dentro dos padrões estabelecidos e consomem os produtos adequados. O fantasma da velhice aparece como uma advertência para as mulheres que não seguem os recursos médico-cosmetologistas.

Pode-se ver, assim, nessas superfícies discursivas, a medicalização dos corpos, a criação de um novo invólucro, de uma nova categoria: as mulheres na menopausa. Vaginas desérticas, ossos quebradiços, desejo esquecido, o discurso médico generaliza e cria a menopausa como um castigo, num corpo envelhecido, caminho de todas, se... não seguirem a hormonoterapia, os cuidados com a pele e os cabelos, a ginástica, a dieta.

O corpo tecnológico é o corpo moderno da mulher e o envelhecimento pode ser driblado em novos estágios de sedução, renovação do dispositivo da sexualidade em novas práticas, em desdobramentos da indústria da beleza e da juventude eterna: médica, cirúrgica, farmacêutica, cosmética.

Essa construção discursiva dos corpos, fraturados em hierarquias de idade, volume, altura e classificados pelo olhar paradigmático que define as possibilidades de sedução, performance, realização pessoal, cristaliza-se em práticas delimitadoras de um sexo biológico atreladas às representações do gênero feminino. Assim o sexo é desenhado não como uma superfície neutra de inscrição de práticas generizadas mas é igualmente un constructo que se erige em dado natural. Para Donna Haraway (1991:35758), “(...) não se nasce organismo. (...) os corpos como objeto de conhecimento são nódulos generativos materiais e semióticos. Seus limites se materializam na interação social. (...) Os vários corpos em questão emergem da interação da investigação científica, da escrita e da publicação, do exercício da medicina e de outros negócios, das produções culturais de todas as classes, incluídas as metáforas e as narrativas disponíveis (...)".

Outro artigo fala das mulheres que exercem profissões masculinas, "não-tradicionais", vencedoras de um concur- 
so promovido pelo Estado para estimular as mulheres a abrirem o leque de suas atividades. No Québec os movimentos feministas, tanto acadêmicos quanto sociopolíticos, abriram um espaço excepcional para a atuação das mulheres. As discriminações são atenuadas mas existem em termos de representatividade política e de desigualdade de salários, nas manifestações da violência social contra as mulheres em todas suas dimensões, da conjugal à prostituição. Assim, em níveis representacionais, igualmente as mulheres encontram-se em patamares assimétricos. De quatro entrevistadas, três têm nível médio e todas desviaram-se para uma carreira masculina, após um início em cozinha, contabilidade e moda. Se o texto demonstra a competência das mulheres, na pesca, na topografia e em tecnologias de elaboração de papel, são apresentadas, no entanto, como minoria, como casos excepcionais e uma delas se destaca como "diferente": aparência esportiva, medalha de bronze no campeonato canadense de futebol. Mulheres, mas nem tanto.

A única entrevistada de nível superior, vice-presidente de um banco, teve um início profissional clássico para as mulheres, transitando indecisa, entre o teatro, assistência social, literatura, história, etc. Mesmo tendo chegado a esse posto, continua em dúvida se não irá se dedicar ao serviço de desenvolvimento na África. A dúvida, a dedicação aos outros... traços marcantes do feminino. Com 36 anos para um homem esse posto seria o resultado de uma bela e rápida carreira; ela, entretanto, sublinha que "não digo que minha vida profissional teve precedência sobre minha vida pessoal, mas eu gostaria que as duas tivessem tido o mesmo sucesso." A imagem publicitária da executiva dura e sem prazer forma rede com esta representação da mulher de sucesso, porém triste. A escolha é óbvia: ou a profissão e a carreira ou a felicidade. Mesmo com o espaço institucional aberto, o campo representacional restringe a atuação das mulheres, sancionando-as em sua vida pessoal.

A revista Elle-Québec, que completa o corpus desta análise, traz em sua capa chamadas em torno do "Sexo, rendez-vous para o amor!"; "Moda, a magia da meia-noite"; Metamorfose, três mulheres se prestam a este jogo"; "As mulheres do ano: heroínas, militantes, estrelas..." e finalmente "Todo o seu ano em nosso especial Astro".

A moda nessa publicação ocupa 40 páginas e produtos de beleza, apenas 34; na La Chatelaîne seu espaço é menor, 9 páginas, e nas revistas brasileiras, 28 em Marie Claire e 48 em Nova. Uma vez construído o corpo é preciso vesti-lo e a indústria da moda, assim como a cosmetologia e os perfumes, é o pilar das revistas femininas. Barthes (1981:262-63) comenta: “Assim é a Mulher ordinariamente significada pela retórica da Moda: feminina imperativamente, jovem absolutamente, dotada de uma identidade forte e entretanto de uma personalidade contraditória (...) seu trabalho não a impede de estar presente em todas as festas do ano e do dia; ela sai todo fim de semana e viaja todo o tempo (...) a mulher da Moda é ao mesmo tempo o que a leitora é e o que sonha ser". Analisa ainda que a Moda seleciona os corpos aos quais se aplica, excluindo outros, ou então cria os corpos "na moda", de acordo com o modelo ideal: “(...) alonga, incha, reduz, aumenta, diminui, afina e por estes artifícios a Moda afirma que pode submeter não importa que acontecimento (não importa o corpo real) à estrutura que ela postula”. A tirania da moda não é uma palavra vã: os corpos se espremem e se contorcem para se ajustar aos contornos da moda.

Se nos ativermos às reportagens anunciadas pela capa, as mulheres do ano, que marcaram o Québec em 1998, são cineastas, artistas, modelos, escritoras, designers, comunicadoras, pequenas empresárias, mas ao lado das profissões o destaque para certas mulheres é também dado por suas qualidades "naturais": altruísmo (freira) e maternidade (25 filhos). Profissões tradicionais ou ligadas ao representacional feminino; por outro lado, a astronauta que aparece no fim da reportagem "é do calibre das estrelas"; a diretora-geral da Banque Royale no Québec "está engajada em muitas causas humanitárias e é a mãe de Anne-Sophie".

Na reportagem seguinte, "o encontro com o amor" é um homem que detém o poder da palavra: na introdução ele afirma que a liberação de uma moral repressiva em relação à sexualidade trouxe "solidão e sofrimento". Salienta que as conquistas modernas foram: a desculpabilização do prazer, a emancipação das mulheres e o fim do ostracismo dos homossexuais, o que localiza seu discurso na atualidade. Mas indica tabus fundadores: incesto, pedofilia e violência conjugal colocando na mesma categorização práticas sociais correntes que longe de representarem um tabu são elementos de disseminação do poder generizado.

Continua incentivando a reapropriação da "verdadeira dimensão da sexualidade" - que naturalmente ele sabe qual é - e recusa "a acomodação com um mundo sem valores nem finalidade". Mas o melhor de seu discurso é sobre o feminismo, marcando bem sua distinção em relação ao feminino, pois mostra à "nova" mulher moderna, a mu- 
lher que lê a revista, sua verdadeira dimensão: “A emancipação das mulheres já estando adquirida (ou quase) vemos aparecer intelectuais que chamarei de pós-feministas. Elas aceitam a herança da emancipação, mas rompem com o feminismo de ontem - o de Simone de Beauvoir que designava à mulher um projeto de masculinização (tornar-se igual ao homem). Essas novas mulheres se querem liberadas mas mulheres no pleno sentido do termo, capazes de pôr em relevo sua especificidade feminina, entre elas a maternidade, que Beauvoir recusava." Esse é um típico discurso didático: "liberadas, mas..." a verdadeira mulher sabe seu lugar, que não é igual ao do homem.

Quem é ela? A de Rousseau? A de Proudhon? Assim, tudo o que era possível já foi conseguido e o feminismo acabou?, interrogação com a qual se deu início a esta análise. Sua esperança é a família "célula necessária a toda sociedade", cuja fundamentação está em sua afirmação apoiada na teia representacional sobre a qual se constitui. Esses são axiomas explicativos baseados nos contratos veridictórios entre o emissor e o receptor, em que a autoridade de quem fala se encontra com a crença de quem ouve. Como sublinha Angenot (1989:33), “(...) lugares comuns do jornalismo (...) que repelem os enunciados incompatíveis e se constroem uns em relação aos outros como co-inteligíveis (...) permitindo dissertar sobre todas as coisas e dominando em ‘baixo contínuo' o rumor social”.

Tereza de Laurentis (1987:3) afirma que "a representação do gênero é sua construção", mas podemos igualmente refletir o corpo como uma construção representacional em modelos de gênero, pois passa-se da idéia de diferença sexual à observação dos mecanismos, do processo de construção cultural dos corpos sexuados, definidos em práticas normativas de sexualidade (Mathieu, 1991:133).

As tecnologias da mídia e especialmente as revistas femininas elaboram, em torno do aparelho genital, os contornos e limites de um corpo sexuado impregnado de valores, crenças, atualizando e reafirmando representações que passam a existir nas práticas que as elaboram. Assim, o corpo construído em feminino exprime as modalidades culturais que o confinam a um gênero que se torna inteligível “(...) na medida em que mantém relações de coerência entre sexo, gênero, prática sexual e desejo" (Butler, 1990:17).

As matrizes de inteligibilidade que constróem esse corpo naturalizado em sexo feminino podem ser identificadas em torno da família heterossexual e de atributos essencializados na "verdadeira mulher": sedução, maternidade, submissão, altruísmo, abnegação.
Para Foucault (1987:126), o corpo está sempre inserido em uma teia de poderes que lhe ditam proibições e obrigações, coerções que determinam seus gestos e atitudes e que delimitam e investem seu exercício e suas práticas, mecanismos de se construir o corpo inteligível num campo político de utilidade-docilidade. Essa é a "disciplina", um sistema de sujeição que cria um 'saber' sobre o corpo "(...) que não é exatamente a ciência de seu funcionamento, e um controle de suas forças que não é mais que a capacidade de vencê-las: esse saber e este controle constituem o que se poderia chamar a tecnologia política do corpo" (Foucault, 1987:26).

No discurso da mídia vimos em funcionamento uma das tecnologias de produção do corpo sexuado, o aparato da produção do corpo feminino útil e dócil dentro das normas heterossexuais, que instituem o binário inquestionável do sexo biológico no social fazendo funcionar, no jogo da linguagem e da imagem, os mecanismos de assujeitamento à norma. Feminismo? Mais do que nunca necessário, pois lendo-se as revistas "femininas" percebe-se que as representações instrumentadoras das práticas sociais hierarquizadoras apenas modificaram os trajes que revestem os mesmos corpos definidos em sexo.

\section{NOTAS}

E-mail da autora: astarteh@hotmail.com

Publicado em francês, no Cahiers d'Etudes Féministes. Montreal, Université de Québec à Montréal - UQAM, n.6, 2000.

1. As citações de obras em língua estrangeira são traduzidas livremente pela autora. (Maingueneau, 1993).

2. "On ne naît pas femme, on le devient", frase que se tornou clássica na literatura feminista.

3. Ver por exemplo a satanização da mulher no Ocidente em Delumeau, (1978) Ver igualmente o livro de Groult (1993), que compila citações masculinas dotadas de autoridade sobre a mulher na história.

4. “(...) De forma geral, a toda formação discursiva é associada uma memória discursiva constituída de formulações que repetem, recusam e transformam outras formulações." (Foucault, 1987:115).

5. Nesta mesma obra a autora faz uma tipologia das relações sexo/gênero levando em conta sua pluralidade.

6. A palavra histérica vem do grego Husteriko, de Hustera (útero), definida como "atitude de doentes, considerada antigamente como um acesso de erotismo mórbido feminino" (Rey e Rey, 1995).

7. A escolha dos números das revistas foi totalmente arbitrária e a baliza temporal vai de dezembro de 1998 a maio de 1999.

\section{REFERÊNCIAS BIBLIOGRÁFICAS}

ANGENOT, M. 1889, un état du discours social. Montréal, Le Préambule,1989. BARTHES, R. Système de la mode. Paris, Seuil, 1981.

BARTKY, S.L. "Foucault, feminity and patriarchal power". In: DIAMOND, I. e QUIMBY, L. Feminism and Foucault. Boston, Northeastern University Press, 1988. 
BORDO, S. "O corpo e a reprodução da feminidade: uma apropriação feminina de Foucault ". In: JAGGAR, A. e BORDO, S. Gênero, corpo e conhecimento. Rio de Janeiro, Rosa dos Ventos, 1997.

BUTLER, J. Gender trouble. Feminism and the subversion of identity. Nova York, Routeledge, 1990.

DELUMEAU, J. La peur en Occident, XIV-XVIII è siècles. Paris, Fayard, 1978.

ECO, U. Apocalípticos e integrados. São Paulo, Ed. Perspectiva, 1993.

ELLE-QUÉBEC. Canadá, n.113, janvier, 1999.

FALUDI, S. Backlash, la guerre froide contre les femmes. Paris, Ed. Des Femmes, 1991.

FLAX, J. "Pós-Modernismo e relações de gênero na teoria feminista". In: HOLANDA, H.B. de (org.). Pós-modernismo e política. Rio de Janeiro, Rocco, 1991.

FOUCAULT, M. Histoire de la sexualité. v.I. Paris, Gallimard, 1976. . A microfísica do poder. Rio de Janeiro, Graal, 1979.

. A arqueologia do saber. Rio de Janeiro, Forense, 1987.

Vigiar e punir. Petrópolis, Vozes, 1987.

A microfísica do poder. Rio de Janeiro, Graal, 1988.

. L'ordre du discours. Paris, PUF, 1991 (tradução livre das citações de obras em língua estrangeira).

GREER, G. La femme eunuque. Paris, Robert Laffont, 1971.

GROULT, B. Cette mâle assurance. Paris, Albin Michel, 1993.

HARAWAY, D.J. Ciencia, cyborgs y mujeres, la reinvención de la naturaleza. Valença, Editiones Cátedra, 1991.
INSTITORIS, H. e SPRENGER, J. Le marteau des sorcières, Malleus Maleficarum - 1486. Grenoble, Ed. Jerôme Million, 1990 (traduit du latin et précédé de l'Inquisiteur et ses sorcières par Amand Danet).

JODELET, D. Les représentations sociales. Paris, PUF, 1994.

LA CHATELAÎNE. "Le mensuel féminin le plus lu au Québec". Canadá, décembre 1998.

LAURENTIS, T. de. Technologies of gender, essays on theory, film and fiction. Bloomington, Indiana, University Press, 1987.

MAINGUENEAU, D. Novas tendências em análise do discurso. Campinas, Ed. Unicamp, 1989

. "Analyse du discours et archive". In: PEYTARD, J. e MOIRAND, S Configurations discursives. Paris, Les Belles Lettres, 1993.

. Les termes clés de l'analyse du discours. Paris, Ed. Seuil, 1996.

MARCONVILle, J. de. De la bonté et de la mauvaiseté des femmes - 1564 Paris, Côté-femmes, 1991

MARIE CLAIRE. "Chique é ser inteligente”. Editora Globo, n.98, maio 1999.

MATHIEU, N.-C. L'anatomie politique, catégorisations et idéologies du sexe. Paris, Côté-Femmes, 1991.

NOVA/Cosmopolitan. "A revista feminina mais vendida no mundo". São Paulo, Ed. Abril, ano 27, n.6, jun. 1999.

REY, J. e REY, A. Le nouveau Petit Robert. Paris, 1995.

RICH, A. "La contrainte à l'hétérosexualité et l'existence lesbienne". Nouvelles Questions Féministes. Ed. Tierce, n.1, p.15-43, mars, 1981.

SWAIN, T.N. "De deusa a bruxa: uma história de silêncio". Humanidades. Brasília, Edunb, s.d. 